\title{
Anthony Ashley Cooper Shaftesbury
}

\section{Dobro i zło*}

* [Podstawą przekładu jest tekst zamieszczony przez Benjamina Randa w zbiorze The Life, Unpublished Letters and Philosophical Regimen of Anthony, Earl of Shaftesbury (London-New York: Swan Sonnenschein-Macmillan Co, 1900), 53-59. Przypisy w nawiasach kwadratowych pochodzą od tłumaczy.

Pod względem tematyki fragment ten rozwija problematykę etyki stoickiej, na co wskazuje przeciwstawienie rzeczy bezwzględnie dobrych (cnót) oraz obojętnych, dotyczących ciała, a także kwestia zasadniczego, właściwego wyboru: opowiedzenia się za dobrem duszy. Kiedy Shaftesbury wspomina o „radości duszy i umysłu uwolnionych od podszeptów, poruszeń i rozstrojeń zmysłów", wyraźnie słychać w tym stwierdzeniu echa słów Epikteta z Diatrybów: „Nie potrafisz otaczać równą opieką i dóbr zewnętrznych, jakie ci zrządzeniem losu przypadły w udziale, i własnej swej duszy. Jeżeli jednak pragniesz tych pierwszych, zaniechaj troski o tę drugą. W przeciwnym razie nie zachowasz ani tych dóbr, ani swej duszy, i będzie cię żądza miotać w dwóch przeciwstawnych kierunkach. Jeżeli znowu pragniesz otaczać troską swą duszę, musisz zaniechać rzeczy zewnętrznych" (Epiktet, Diatryby. Encheirdion z dodaniem Fragmentów oraz Gnomologium Epiktetowego, przeł. Leon Joachimowicz (Warszawa: PWN, 1961), cyt. za: Giovanni Reale, Historia filozofii starożytnej, t. IV, przeł. Edward Iwo Zieliński (Lublin: Redakcja Wydawnictw KUL, 1999), 131). Tekst ten ma charakter stoickiego ćwiczenia w filozofii (askêmata), ciągłego napominania o bezwzględnym charakterze cnoty w celu wykształcenia i utrwalenia odpowiedniej postawy etycznej, czego przykładem są zarówno spisane przez Flawiusza Arriana nauki Epikteta, jak i Rozmyślania Marka Aureliusza; od strony stylistycznej ujawnia się ów charakter w sposobie kierowania wypowiedzi - jej adresatem jest sam autor. Tekst ten pochodzi z notatnika Shaftesbury'ego, spisywanego w latach 1698-1699 oraz 1703-1704, podczas pobytu filozofa w Holandii, i stanowi zapis solilokwium - rozmowy z samym sobą. Shaftesbury formę takiego wewnętrznego dialogu zastosował także w innych pismach, przede wszystkim w Soliloquy, or Advice to an Author (1710), przy innej zaś okazji pisał: „mam tak silną potrzebę pewnej szczególnej obecności lub towarzystwa, gdy tylko chcę 
Nam quid sequar, aut quem? ${ }^{1}$ Dlaczego miałoby mnie niepokoić, że myślą o mnie, iż jestem inny niż reszta ludzi? Dlaczegóż miałbym nie trwać w podążaniu za tym, co uważam za dobre, skoro tak długo się nad tym zastanawiałem i z takim rozmysłem dobro to wybrałem? - Lecz jest ono czymś dziwnym, niespotykanym, sprzecznym z potoczną opinią. - Za kimże miałbym więc podążać? Na czyj osąd bądź opinię o tym, co jest bądź nie jest dobre, mam zważać?

Kogoś pociąga bohaterstwo; uważa on, że największą w życiu sprawą jest ujrzeć wojnę i wziąć udział w działaniach bitewnych, dlatego z odrazą i całkowitą pogardą spogląda na tych, którzy nigdy niczym takim się nie zajmowali. Ktoś inny śmieje się z niego, uważa to za głupotę i tępotę, ceni sobie swój własny dowcip i roztropność, i uważa, że byłoby dlań kompromitacją, gdyby ktoś uważał go za takiego awanturnika lub gdyby on sam kiedykolwiek zaangażował się w takie niebezpieczne przedsięwzięcie.

Ktoś wytrwale i niestrudzenie stara się zostać człowiekiem interesów i zdobyć odpowiednią pozycję w świecie. Ktoś inny, na odwrót, uważa to za coś niestosownego, nie ceni sobie takiej sławy czy światowego życia i najchętniej nigdy nie opuściłby libacji czy szynku, w którym najbardziej lubi przebywać i który uważa za najwyższe dobro.

Ktoś ceni bogactwa i traktuje je jedynie jako środek do tego, aby zadowolić swe podniebienie wyrafinowanymi potrawami. Ktoś inny tym pogardza, lecz pragnie zdobyć popularność. Jeden podziwia ogrody, architekturę i przepych budynków, inny nie znajduje w tym upodobania i uważa, że ci wszyscy, których zwą wirtuozami, są szaleni.

Ktoś uważa, że zdobywanie doświadczeń to szaleństwo, i sądzi, że jedynym dobrem jest bogactwo. Ktoś oddaje się hazardowi, innego pociągają ubiory

wznieść swe myśli, że kiedy jestem sam, muszę starać się zaspokoić tę potrzebę siłą wyobraźni” (tegoż, List o entuzjazmie, w: List o entuzjazmie. Moraliści, 30)].

1 [Łac.: „Za czym bądź za kim mam podążać?”, Hor. Epi. I, ks. I, w. 76; w polskim przekładzie Listów Horacego słowa te kończą następujący fragment: „Gdy przypadkiem zapyta nie lud rzymski, czemu / inaczej niż on myślę, niż on mówię stale, / Nie stronię, gdy on stroni, gdy chwali, nie chwalę, / Powiem, co rzekł list chytry lwu, gdy był w chorobie: / «Ślady mnie odstraszają, bo wszystkie ku tobie / Wiodą, ale nie zmierzał nikt powrotnym śladem». / Tyś wielogłowy potwór! A świecisz przykładem?..." (Kwintus Horacjusz Flakkus, Dzieła wszystkie. Tom II: Gawędy, Listy, Sztuka poetycka, przeł. Oktawiusz Jurewicz (Wrocław: Ossolineum, 1988, 254-256)]. 
i powozy, ktoś jeszcze inny ma głowę nabitą heraldyką, genealogią i więzami krwi. Jeden zaleca galanterię i intrygi, inny - bunt i rozpustę, jeszcze inny błazenadę, satyrę i prosty dowcip, ktoś - sporty i życie na wsi, ktoś - życie dworskie, ktoś - podróże i zwiedzanie obcych krajów, a jeszcze inny - poezję i modną literaturę. Każdy z nich dąży do czegoś innego. Każdy potępia innych i sam w ich oczach uchodzi za osobę godną pogardy. Czymże zatem mam się zajmować? Czyjego potępienia mam się obawiać? Za czyim przewodnictwem mam podążyć? Jeśli zapytam, czy dobre są bogactwa, które się gromadzi, lecz których się nie używa, jeden mi powie, że tak, inny zaś zaprzeczy. Jak więc mam nimi rozporządzać, aby przyniosły dobro? Nikt się co do tego nie zgadza, każdy mówi mi co innego. Skoro zatem bogactwa nie są dobre same w sobie (jak większość z was twierdzi) i skoro nie możecie się zgodzić, jak miałyby się stać dobre lub jak je dobrymi uczynić, dlaczego nie miałbym uważać, że nie są one ani dobre same w sobie, ani też nie mogą w żaden sposób takie się stać?

Skoro znajdą się tacy, którzy pogardzają sławą, a spośród tych, którzy jej pożądają, ten, kto jej pragnie ze względu na coś jednego, wzgardza nią w przypadku czegoś innego, i skoro ktoś, kto poszukuje sławy jakiegoś rodzaju, wzgardza innymi jej rodzajami, to dlaczego nie miałbym uważać, że nie wiem, jak można sławę określać mianem dobra?

Jeśli ci, który zabiegają o przyjemność i podziwiają jeden jej rodzaj, potępiają inny, to dlaczego mam nie powiedzieć, że nie wiem, która z przyjemności jest dobra, i nie wiem też, jak w ogóle przyjemność może być dobra?

Skoro pośród tych, którzy tak żarliwie miłują życie, ten jego rodzaj, który jest odpowiedni dla kogoś jednego, dla innego jest wstrętny i niegodziwy, dlaczego mam nie powiedzieć, iż nie wiem, dlaczego życie samo w sobie miałoby być $\mathrm{z}$ konieczności dobre?

Tymczasem dostrzegam i z całą pewnością wiem, że konieczną konsekwencją umiłowania i cenienia sobie owych rzeczy jako dobrych jest stanie się zazdrośnikiem, człowiekiem narzekającym, niecierpliwiącym się, często niezadowolonym i zasmuconym, zgorzkniałym, zatroskanym, złośliwym, podejrzliwym i zawistnym, bojącym się tego, co ma się wydarzyć - wszystko to oznacza nieszczęście. $Z$ drugiej strony pogardzanie tymi rzeczami oznacza wolność, wspaniałomyślność, wielkoduszność, samouznanie, świadomość własnej wartości. Czyż jednak nie są one dobre, lecz w sposób niekonieczny, 
tak jak te pierwsze? Wspaniałomyślny afekt, nieprzerwane ćwiczenie się w przyjaźni, niezmienna życzliwość i łaskawość usposobienia, nieustanny spokój ducha, stałe poczucie bezpieczeństwa, spokój i opanowanie - czyż nie są one zawsze, w każdych czasach dobre? Czyż mogą one kiedykolwiek komuś obrzydnąć bądź go znużyć? Czy aby były nam miłe, muszą im towarzyszyć jakieś szczególne czasy, pora roku, miejsce czy okoliczności? Czy są zmienne i niestałe? Czy jeśli ktoś żarliwie je miłuje oraz pragnie, to sprowadzają one nań jakiś niepokój lub nieszczęście? Czy w ogóle można je przecenić? Skoro nie, to w czymże tkwiłoby moje dobro, jeśli nie w nich właśnie?

Dlaczegóż w ogóle muszę podejmować jakieś działanie? Dlaczego dokonuję wyboru? Dlaczego przedkładam jedną rzecz nad inną? Czy dlatego, że pojmuję lub wyobrażam sobie, że tkwi w niej jakieś dobro, czy dlatego, że tam mówi jedynie moja fantazja? Czy mam zatem podążyć za każdym chwilowym fantazmatem i wyobrażeniem dobra? Jeśli tak, to w jednym momencie muszę podążać za czymś, za czym nie będę podążał w innym, w jednym będę cenił to, czym będę w innym pogardzał, i zawsze będzie mi brakowało wewnętrznej stałości. Jeśli jednak nie mam jednakowo podążać za wszystkimi fantazjami i jeśli niektóre $\mathrm{z}$ nich są prawdziwe, inne zaś fałszywe, to muszę sprawdzić każdą z nich, musi zatem istnieć jakaś miara, dzięki której mógłbym je określić i osądzić. Ktoś kiedyś umyślił sobie, że zyska nieśmiertelną sławę, podkładając ogień pod piękną świątynię. Jeśli uznał to za dobro, dlaczegóż ktoś taki miałby nas dziwić? Jeśli to wyobrażenie było złe, to na czym polegało owo zło? Dlaczegóż nie był to dobry czyn, jak sobie to wyobrażał? Dlatego, że albo dla każdego człowieka dobrem jest to, co sobie wyobraża, i ponieważ wyobraża to sobie i bez tego nie może osiągnąć zadowolenia, ale też, na odwrót, jest nim to, co daje zadowolenie naturze człowieka i tylko ono może być dlań dobre. Jeśli jego dobrem jest tylko to, co sprawia zadowolenie jego naturze i daje jej spełnienie, wówczas głupcem jest ten, kto dobrem nazywa przedmiot swych dążeń, jeśli bez niego może się obyć i nie potrzebuje go, aby znaleźć spełnienie i zadowolenie, tak samo jak głupcem jest ktoś, kto ucieka przed czymś, co można znieść i mimo to znaleźć zadowolenie. Może nie trzeba zatem spalić świątyni jak Herostrates, a mimo to osiągnąć satysfakcję. Na tej samej zasadzie można obyć się bez rzeczy, które zwykło się określać mianem dobrych, i być zadowolonym; wręcz przeciwnie: można je posiadać, a mimo to nie zyskać zadowolenia i nie być wcale szczęśliwszym 
niż wcześniej. Jeśli tak jest, to szczęście polega na pewnym usposobieniu i dyspozycji, jest sprawą umysłu i woli. A skoro tak, to dlaczego nie miałbym go właśnie tam poszukiwać?

Wszystko, co jest dobre, musi być jednakowo dobre dla wszystkich, wszystko, co złe, musi być jednako dla wszystkich złe. Smutek, kłopoty, przygnębienie, gonienie za zaszczytami, strach, spokój ducha, satysfakcja, zadowolenie, wolność umysłu, dobre usposobienia, dobre afekty - wszystko, co je tworzy czy ustanawia, jest w podobny sposób dobre bądź złe dla wszystkich ludzi i dlatego jest z natury czymś dobrym bądź złym. Jeśli cnota nie jest konieczna, aby dać satysfakcję i zadowolenie, albo jeśli zadowolenie można osiągnąć równie dobrze $\mathrm{z}$ nią, jak i bez niej, to cnota nie jest naszym dobrem; jeśli zaś jest konieczna dla osiągnięcia zadowolenia, wówczas jest naszym dobrem; wszystko, co dla osiągnięcia zadowolenia jest obojętne, jest obojętne samo w sobie. Otóż jeśli to, co przedstawia mi moja fantazja, jest niezbędne, by mnie zadowolić, musi być także konieczne do zadowolenia każdego innego człowieka. Czy moja fantazja przedstawia mi jako konieczną sławę? Ale przecież nie każdy jej potrzebuje, aby osiągnąć zadowolenie (ponieważ są tacy, którzy mogą żyć usatysfakcjonowani bez niej). Dlatego nie jest konieczna dla mojego zadowolenia i nie jest moim dobrem. Czy to może zaszczyty, czy władza? Tak samo. Czy może bogactwo? Tak samo. A może przyjemność jakiegokolwiek rodzaju? To także. Ani jedno, ani wręcz żadne $\mathrm{z}$ nich z pewnością nie przynosi satysfakcji, ponieważ umysł może być równie niespokojny pośród nich, jak i bez nich. Jeśli zatem to tylko jest dobre, co jest konieczne dla zadowolenia każdego człowieka, to ono właśnie powinno być obecne, a złe jest to tylko, czego brak z konieczności daje zadowolenie każdego człowieka. Zatem pewność przeżycia dwudziestu lat, roku lub godziny nie jest konieczna dla satysfakcji człowieka. Nie jest też konieczne dla jego zadowolenia, by wierzył czy nie wierzył w to, że umrze w przyszłym roku lub w następnej godzinie. Dlatego pewność śmierci w przyszłym roku czy w kolejnej godzinie nie ma znaczenia i dlatego śmierć nie jest złem. Jeśli ból jest zły, musi być tak samo zły dla wszystkich ludzi (podobnie jak smutek, niedola, zaszczyty, rozpacz, niepokój i temu podobne). Ale jeśli istnieje pewien typ charakteru lub postanowienie, dzięki którym można zlekceważyć ból, to nie jest on zły dla tego, kto ma taki temperament lub zdobył się na to postanowienie, ale dla tego, kto tego chce, a zatem nie zawsze i sam w sobie jest on zły. 
Jeśli zaś powiada się, że ból jest zły, to jednak nie każdy ból jest taki; ponieważ to, co dla zniewieściałego człowieka jest nieznośnym bólem i kłopotem, dla człowieka ciężko pracującego lub bitnego jest przedmiotem przyjemności i uciechy. Czymże jest przyjemność sportowców lub tych, którzy kochają przygody i angażują się w rzeczy niebezpieczne, jeśli nie tym, co wiąże się z bólem i trudem? Jaka jest różnica między tym, kto jest silny i męski, a tym, kto słaby i delikatny, jeśli nie to, że to, co pociąga jednego, nie angażuje drugiego? Dlatego też, skoro jedni tolerują największe cierpienie, a dla innych najmniejszy ból jest nie do zniesienia, to czy nie należy brać pod uwagę jedynie największego bólu i raczej tego, co powoduje, że ból sprzyja dobru lub złu tudzież bywa tolerowany lub uznawany za nie do zniesienia? Dlatego też bólu, śmierci, ubóstwa czy zapomnienia nie powinno się uważać za zło. Z drugiej strony przyjemności, bogactwa, zaszczytów ani sławy nie powinno się uważać za rzeczy przyczyniające się do naszego szczęścia lub dobra. Ponieważ jednak obawialiśmy się tych pierwszych jako złych, czy też goniliśmy za tymi drugimi jako dobrymi, muszą istnieć niepokoje, rozczarowania, obawy, zazdrość, zawiść czy wrogość, które są i wiecznie będą złe i żałosne. Tak i przeciwnie, wolność od nich musi nieść pokój ducha, spokój, bezpieczeństwo, niezakłóconą radość wszystkich afektów społecznych oraz ćwiczenie wszystkich cnót, które są i muszą być wiecznie dobre i wiodące do szczęścia.

Tego, kto jest poruszony przez to, co nie leży w jego mocy, lub jest zniechęcony przez to, czego nie może uniknąć, nie można nazwać zadowolonym. Dlatego ten, kto dąży do właściwego afektu, dąży do szczęścia, zadowolenia i dobra. Ten, kto gardzi takim afektem lub twierdzi, że może być zadowolony bez niego, sam sobie zaprzecza i równie dobrze może powiedzieć, że potrafi być zadowolony bez zadowolenia.

Dobro życia leży albo w odczuciach ciała, albo w poruszeniach i afektach duszy, albo w działaniu umysłu w myślach i kontemplacji lub, jeśli nie występuje osobno $\mathrm{w}$ jednym $\mathrm{z}$ nich, musi znajdować się $\mathrm{w}$ ich pewnym zmieszaniu. Jeśli byłoby tylko w zmysłowości, wówczas już u zwierząt byłoby ono dopełnione i najdoskonalsze, ponieważ mają one większą po temu zmysłową sposobność oraz nie są obarczone niczym więcej.

Jeśli dobro życia znajduje się w duszy i umyśle, ale jest podporządkowane zmysłowości, nic się nie zmienia, ponieważ jeśli osiągnięte zostanie najwyższe dobro (załóżmy, że w zmysłowości), to dusza i umysł mają mniejsze 
znaczenie, a zatem stan zwierzęcości jest najdoskonalszy. Jeśli dobro w najwyższym stopniu i przede wszystkim przynależy duszy i umysłowi, wówczas ciało pozostaje im podporządkowane, należy zaś rozważyć, jak daleko posunięte jest to podporządkowanie. Teraz staje się oczywiste, że ponieważ aktywność umysłu i działanie duszy są przyczyną tego, że przyjemności zmysłowe są odczuwane w mniejszym stopniu, a przez to umniejszają dobro właściwe zmysłowości. Z drugiej strony zmysłowość jest przeszkodą dla osiągnięcia tego dobra, które przynależy umysłowi. Oto opozycja i walka dwóch wskazanych zasad. Dlatego też, jeśli najwyższy stopień tego rodzaju dobra (mianowicie dobra umysłowego) nie będzie osiągalny inaczej niż przez utratę drugiego, to drugie jako dobro niższe trzeba poświęcić na rzecz większego, jedynego prawdziwego i realnego dobra, którym jest radość duszy i umysłu uwolnionego od podszeptów, poruszeń i rozstrojeń zmysłów.

A jeśli najważniejsze dobro znajduje się w duszy i umyśle oraz ich działaniach, rozważ, jak je wyrządzasz i co czynisz przedmiotem ich dążenia i zamiaru. Jak je wykorzystujesz i czym zajmujesz? Jak to jest, że twoja dusza kocha, szanuje, podziwia, raduje się? Czym jest to, o czym twój umysł myśli z zachwytem? Spójrz na te zagadnienia. Albowiem jaka jest ich wartość, taka jest twoja wartość, podobnie jak wielkość i pełnia tego, czym jako dobrem się cieszysz. Zobacz zatem, gdzie jest pełnia, a gdzie pustka. Zobacz, w jakim przedmiocie znajduje się najważniejsza doskonałość i piękno, gdzie jest ono pełne, doskonałe, absolutne, a gdzie zepsute, niedoskonałe, znikome. Zobacz te ziemskie piękności oraz wszystko to, co jawi się jako doskonałe i co jest w stanie nas przyciągnąć. Zobacz, co zarówno istnieje realnie, a co zajmuje miejsce sprawiedliwości, piękna i dobra ${ }^{2}$ : wielkie ambicje, połać ziemi, wielka liczba niewolników, stos kamieni, ludzkie ciało o pewnych liniach i proporcjach. Ale przejdź teraz do tego, co tym bardziej może cię zwieść: przyjaciela, grupy lub wspólnoty przyjaciół, rodziny i tego większego jej rodzaju - miasta, społeczności i kraju ojczystego. Czy to najwyższy rodzaju tego typu? Czy to piękno pierwszego rzędu czy stopnia? Czy wszystko to może być piękne samo, jeśli piękny nie jest świat? Czy piękno i doskonałość mogą tkwić w tych

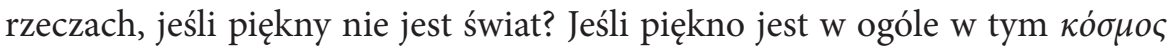
(pierwowzorze i tym, w czym zawierają się wszystkie piękności), to czy może

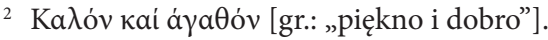


być mniej doskonały jako całość niż w częściach? Czy przeciwnie, nie jest niemożliwe, aby piękno było niedoskonałe w częściach, a doskonałe jedynie w całości - tam, gdzie wszystkie części (jak wyraził się mistrz³) są zestawione (rapportées), dopasowane, dostosowane, gdzie wszystko jest połączone i zjednoczone i gdzie sumuje się wszelka harmonia, $\rho v \theta \mu o ́ c$, a miara i proporcja są zsumowane. Dostrzeż, na czym polega piękno malarstwa, architektury. Czy jest w każdym pociągnięciu pędzla lub kamieniu, które jednoczą się w całym dziele? Czy tkwi ono w osobnych, drobnych częściach, czy w całości? Czy (przypuśćmy) w stopie kwadratowej budynku, czy może w calu kwadratowym obrazu? Czy też nie jest oczywiste, że gdyby wzrok ograniczał się jedynie do nich, utracilibyśmy główne i dominujące piękno, niezależnie od tego, jakie subtelne wdzięki objawiałyby się nam w tych niedoskonałych fragmentach? Teraz zastanów się i posłuż się tym, co powiedziane, rozważ obraz i samą architekturę, zbadaj muzykę i harmonię, głos, twarz - do czego się odnoszą? Jak się mają do całości? Czego są obrazem, odbiciem, cieniem? Gdzie mieści się najwyższe piękno? Gdzie najwyższe dobro?

Zobacz zatem, co jest miłe na pierwszym szczeblu, a co na drugim, niższym. Podążaj za tym, co pierwsze. Idź do źródła, początku oraz zasady doskonałości i piękna. Zobacz, gdzie mieści się idealne piękno, bo tylko tam możesz dostąpić doskonałej przyjemności i najwyższego dobra.

Przekład i opracowanie: Adam Grzeliński

Uniwersytet Mikołaja Kopernika w Toruniu e-mail: Adam.Grzelinski@umk.pl

ORCID: 0000-0002-4007-6507

Dawid Wincław Uniwersytet Mikołaja Kopernika w Toruniu e-mail:dwinclaw@doktorant.umk.pl ORCID: 0000-0002-0738-4057

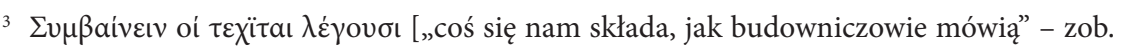
Marek Aureliusz, Rozmyślania, ks. 5, rozdz. 8, przeł. Marian Reiter (Kęty: Wydawnictwo Marek Derewiecki, 2019), 42]. 